\title{
Determinants of Household Waste Segregation in Gorkha Municipality, Nepal
}

\author{
Bijan Maskey ${ }^{1}$ \\ ${ }^{1}$ Graduate School for International Development and Cooperation, Hiroshima University, Higashi-Hiroshima, \\ Hiroshima, Japan \\ Correspondence: Bijan Maskey, Graduate School for International Development and Cooperation, Hiroshima \\ University, 1-5-1 Kagamiyama, Higashi-Hiroshima, Hiroshima 739-8529, Japan. Tel: 81-80-4558-3834. E-mail: \\ mr_bijan@hotmail.com
}

Received: November 28, 2017

doi:10.5539/jsd.v11n1p1
Accepted: December 16, $2017 \quad$ Online Published: January 4, 2018

URL: https://doi.org/10.5539/jsd.v11n1p1

\begin{abstract}
Municipal solid waste management is a huge challenge specially in the developing countries. The first and fundamental step to solve the problem of municipal solid waste management is by waste segregation at source and separate collection of waste, which will help to recover recyclable materials and reduce the amount of waste that needs to be disposed at the dumpsite or landfill site. In Nepal, waste segregation at source is mandated by law but the government is not able to implement it successfully. This paper assesses the willingness of the households to practice waste segregation in future if the government enforces the law and various factors that influences the practice. Data was collected from 401 households which was selected using stratified sampling technique from all the municipal wards, the lowest administrative units in Nepal. The finding shows that about $67 \%$ of the respondents are willing to segregate waste in future if the government enforces the law. Logit regression model was employed to identify the factors that influence waste segregation practice. The significant variables found from this study are environmental awareness, waste collection service, willingness to pay, make compost, and segregated waste for a week variables, which are statistically significant at $1 \%$ level of significance. Income variable is significant at $5 \%$ level of significance and gender variable is significant at $10 \%$ level of significance. It is recommended that the concerned stakeholders should educate the households on the importance of waste segregation and consider these traits of households before enforcing the law.
\end{abstract}

Keywords: Nepal, household waste segregation, municipal solid waste management, stratified sampling, logit regression model

\section{Introduction}

With the rapidly increasing urbanization and population growth along with the changing consumption pattern, the amount of global solid waste generation has increased significantly over the years. In 2012, 1.3 billion tonnes of solid waste was generated by urban population globally which is about $48 \%$ increase over the past 10 years and it is expected to increase to 2.2 billion tonnes by 2025 (Hoornweg \& Bhada-Tata, 2012). Municipal Solid Waste Management (MSWM) is a growing concern and to effectively manage solid waste is a major challenge for any country. MSWM is inadequate in most of the cities of developing countries, where a significant portion of the population does not have access to a waste collection service and only a fraction of the generated waste is actually collected. Developing countries faces even bigger challenge as huge amount of investment is required for MSWM. About 20-50\% of municipal budget is spent on MSWM and in spite of spending almost half of the municipal budget, about $30-60 \%$ of the wastes are uncollected and less than $50 \%$ of its population is served (The World Bank, 2016). The uncollected waste, which is often mixed with human and animal excreta, is dumped indiscriminately in the streets, banks of the river and in drains which contributes to flooding, breeding of insects and rodent vectors leading to spreading of diseases. Furthermore, even collected waste is often disposed off in uncontrolled dumpsites and/or burnt, polluting water resources, air and environment (Zurbrugg, 2002). Such inadequate waste disposal creates serious environmental problems that affect health of humans and animals and cause serious economic and other welfare losses. The environmental degradation caused by inadequate disposal of waste can be expressed by the contamination of surface and ground water through leachate, soil contamination through direct waste contact or leachate, air pollution by burning of waste, spreading of diseases by different 
vectors like birds, insects and rodents, or uncontrolled release of methane by anaerobic decomposition of waste.

Nepal is one of the least developed countries in the world. With the total area of 147,181 square kilometers, Nepal has the population of over 26 million (Central Bureau of Statistics [CBS], 2014b), which is 13.03\% increase over the past ten years. In nominal terms, per capita consumption increased from NRs. 6,802 in 1995/96 to NRs. 15,848 in 2003/04. Average household income grew by more than $80 \%$ from 1995/96 to 2003/04. During the same period, per capita income increased from NRs. 7,690 to NRs. 15,162 (Central Bureau of Statistics, 2004).

Population and purchasing power has a direct correlation with the generation of solid waste. With the increasing population and purchasing power, more and more solid waste is being generated and Nepal is facing even more difficulty and challenge to deal with solid waste. With urbanization, comes rise in the amount of municipal solid waste generation and the problems of managing such waste. Waste can be a valuable resource if used properly but if remained untreated, it can cause serious environmental and public health hazards. In Nepal, only about $62.3 \%$ of municipal waste is collected and managed by the municipalities (Asian Development Bank [ADB], 2013).

Segregation of waste at source and separate collection of waste is the first and fundamental step to solve municipal household solid waste problem (Chu, Wang, Wang, \& Zhuang, 2016). Waste segregation at household level can preserve the quality of recyclables, which will improve the accessibility to informal recycling sectors and help in overall reduction of waste for disposal (Matter, Dietschi, \& Zurbrügg, 2013). In order to make recycling a success, political, economic, social conditions and most importantly the attitudes of people plays a crucial role (Ball \& Lawson, 1990; De Feo \& De Gisi, 2010a; Martin, Williams, \& Clark, 2006; McDonald \& Oates, 2003; Perrin \& Barton, 2001; Tonglet, Phillips, \& Bates, 2004).

Policy implementation is a huge challenge for the government and it may not be successful if there is a lack of clarity and awareness by the stakeholders and if it is not strictly enforced (Mani \& Singh, 2016). Compulsory recycling program implemented by the government can have a higher participation rate than voluntary recycling by the resident (Everett \& Peirce, 1993; Noehammer \& Byer, 1997). Technological dimension has greatest impact followed by political, economic and sociocultural dimensions on effectiveness of municipal household solid waste separate collection (Chu et al., 2016).

Therefore, waste segregation at source, i.e. at the household level plays a very important role to effectively manage municipal waste. Although Solid Waste Management Act of Nepal, 2011 has clearly stated the provision for segregation of the solid waste, for which the local body is given the full responsibility to enforce segregation of solid waste at source, it has hardly been made into practice. A study conducted by ADB (2013) in all the then 58 municipalities of Nepal found that only $30 \%$ of the surveyed households were segregating waste at source. Waste segregation has not yet been implemented in the study area. Hence, this study makes an effort to understand the current solid waste management situation and practices in Gorkha municipality of Nepal, and assess the willingness of the household to practice waste segregation if the government enforces the law. There have been no similar studies conducted in Nepal; hence the findings from this study can be taken into considerations by the concerned stakeholders to implement waste segregation in the study area and other municipalities of Nepal.

\section{Material and Methods}

\subsection{Study Area}

This study was conducted in Gorkha municipality of Nepal (Figure 1). It has an area of 83.55 square kilometers. It has an average temperature of $25^{\circ} \mathrm{Celsius}$ with an average annual rainfall of 149.2 millimeter $(\mathrm{mm})$. There are 15 wards, the smallest administrative units in Nepal, with a population of 39,172 residents and a total of 9,236 households. The average size of the household is 3.69, which is lower compared to the national average of 4.21 (CBS, 2014b). 


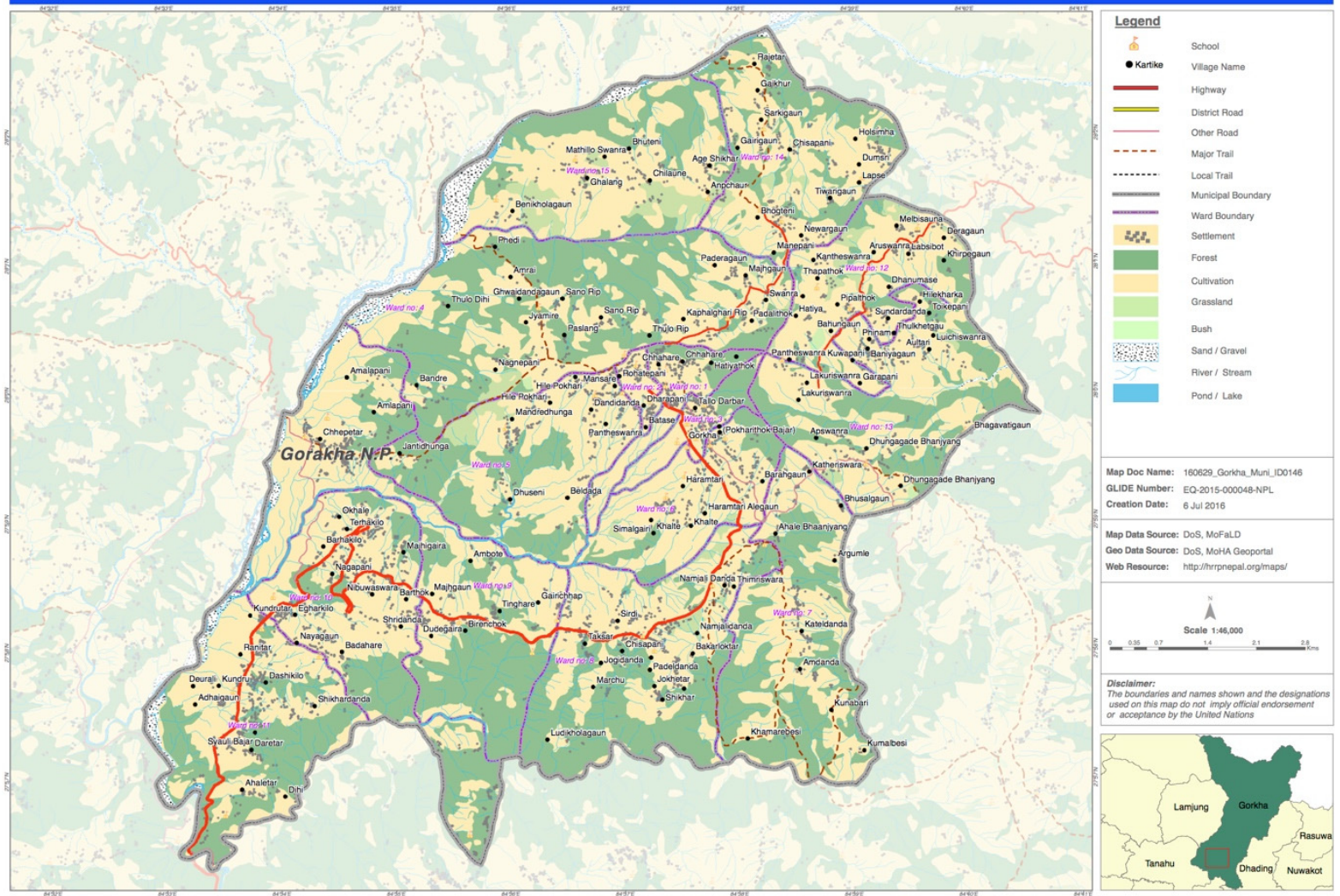

Figure 1. Map of Gorkha municipality

Source: Housing Recovery and Reconstruction Platform - Nepal [HRRP] (2016)

\subsection{Sampling Procedure and Data Collection}

Sample was selected using stratified sampling technique where each ward was taken as a stratum. Sample size was selected based on simplified formula for proportions by Yamane (1967).

According to Yamane, at 95\% confidence level,

$$
n=\frac{N}{1+N(e)^{2}}
$$

Where $n$ is the sample size, $N$ is the population size, and $e$ is the level of precision.

At $95 \%$ confidence level and 5\% precision level, the required sample is 383 households. 383 households were proportionally divided among 15 wards. Additional $10 \%$ of households from all 15 wards were selected to avoid shortcomings of partly filled questionnaire and non-response. Final sample households selected for this study is 401 households that gives a $4.88 \%$ precision level at $95 \%$ confidence level and a response rate of about $95 \%$.

Households were requested to segregate waste into degradable and non-degradable waste for a week to assess waste generation and characterization of household waste in Gorkha municipality. After a week, the waste was collected and waste generation and characterization study was conducted. All the participant households were approached with the semi-structured questionnaire. The semi-structured questionnaire included questions related to the socioeconomic characteristics of the households, current SWM practices, services provided by the municipality, awareness about the impact of waste on environment, willingness to pay for improved waste collection service, whether they segregated waste for a week or not, and willingness of the households to segregate waste if the government enforces the law. This paper focuses on the willingness of the households to segregate waste if the government enforces the law in near future and identify various factors that influences households' waste segregation practices. 


\subsection{Empirical Model}

Logit regression model was used in this study to identify the determinants of households' willingness to segregate waste into degradable and non-degradable waste if the government enforces the law in near future. Logit model was used because of its comparative mathematical simplicity and asymptotic characteristics, as has been mentioned and used by many other authors (Addai \& Danso-Abbeam, 2014; Aggrey \& Douglason, 2010; Anjum, 2013; Awunyo-Vitor, Ishak, \& Jasaw, 2013; Bhattarai, 2015; Mary \& Adelayo, 2014; Oteng-Ababio, 2010; Song, Wang, \& Li, 2016). It has a cumulative probability function with the ability to deal with dependent variable which allows for estimating the probability that an event will occur or not through prediction of a binary dependent outcome from a set of independent variables (Aggrey \& Douglason, 2010). The logit model to identify factors influencing households' willingness to segregate waste can be specified as:

$$
Y=\frac{1}{1+\exp ^{-\mathrm{z}}}
$$

where,

$Y=$ Respondents' response for willingness to segregate waste $(\mathrm{Yes}=1$, No $=0)$

$Z=$ Summation of explanatory variables multiplied by their coefficient, i.e.,

$$
Z=\beta_{0}+\beta_{1} X_{1}+\beta_{2} X_{2} \ldots \ldots+\beta_{9} X_{9}+\varepsilon_{i}
$$

where,

$\beta_{0}=$ Constant

$\beta_{1} \ldots \ldots \beta_{9}=$ Coefficient of explanatory variables $X_{1} \ldots \ldots X_{9}$

$\varepsilon_{\mathrm{i}}=$ Error term

To find out the probability of households' willingness to segregate waste, the parameters from logit model cannot be used to interpret effects of each of the explanatory variable as the model is nonlinear. In this case, marginal effects are calculated to find the relative magnitude of effects of each of the explanatory variable. The effects of the $j$ th explanatory variable can be summarized as below:

$$
\frac{1}{n} \sum_{i=1}^{n} \frac{\partial P\left[Y_{i}=1\right]}{\partial X_{j i}}=\beta_{j} \frac{1}{n} \sum_{i=1}^{n} f\left(X_{i}^{\prime} \beta\right), \quad j=2, \ldots, k .
$$

i.e., the mean marginal effects over the sample of $n$ individuals.

Maximum likelihood method is used to estimate the parameters of the multiple logistic response function. The log-likelihood function is as follows:

$$
\log L(\beta)=\sum_{i=1}^{n} Y_{i}\left(X_{i}^{\prime} \beta\right)-\sum_{i=1}^{n} \log \left[1+\exp \left(X_{i}^{\prime} \beta\right)\right]
$$

\subsection{Variables Selection}

Financial incentive is one of the significant factor that influence separate waste collection. Financial incentive policies should be made by the government to encourage more public participation for recycling (Steuteville, 1995). Economic incentives significantly influence recovery of recyclables at the household level (Yau, 2010).

Environmental awareness and concern influences the behavior of the people (Desa, Kadir, \& Yusooff, 2011; Minton \& Rose, 1997) for effective recycling program to be successful (Derksen \& Gartrell, 1993; Miafodzyeva \& Brandt, 2013), which can also have an impact on waste segregation for proper waste management.

Zhang and Wen (2014) found that waste segregation at household level is influenced by age, source separation facilities and government policies. De Feo and De Gisi (2010b) found that older age group of participants were more satisfied than the younger ones for separate waste collection programs for recycling. Convenience and existence of infrastructure are important factors that can influence segregation of waste at source (Bernstad, 2014). Lack of knowledge is one of the major factors that prevents people from recycling and females are more likely to participate in waste recycling than males (Otitoju, 2014). A study by Lober (1996) found that recycling is more efficient and accepted by the participants than waste reduction activities at source. 
Information about recycling, condition of recycling facility and personal recycling skills influence the recycling behavior (Ittiravivongs, 2012). Number of household member and household who does environmental protection activities such as waste water treatment and waste reduction influences recycling behavior of the household (Kato, Tran, \& Hoang, 2015). Households' participation in solid waste segregation and recycling activities are influenced by the promotional campaign, training programs and age of the residents (Atthirawong, 2016). Study by $\mathrm{Xu}$ et al. (2017) found that the effect of governmental incentives on recycling behavior is greater on male than female and income of the household negatively influences recycling behavior. Low income households are more likely to recycle than higher income households.

The explanatory variables used in this study are based on the assumption that it will influence on the respondent's decision to segregate or not to segregate waste in the future. The explanatory variables used in this study are described in Table 1.

Table 1. Description of explanatory variables used in this study

\begin{tabular}{|c|c|c|}
\hline Variable & Description & Unit of Measure \\
\hline Income & Total average monthly income of household & $\begin{array}{l}\text { Nepalese Rupee (NRs.) } \\
(1 \mathrm{US} \$=\text { NRs. 102.13)* }\end{array}$ \\
\hline Household size & $\begin{array}{l}\text { Total number of members currently residing in } \\
\text { the house }\end{array}$ & Number of individuals \\
\hline Gender & Gender of household head & $\begin{array}{l}1=\text { Male } \\
0=\text { Female }\end{array}$ \\
\hline House ownership & Ownership of currently residing house & $\begin{array}{l}1=\text { Owned } \\
0=\text { Rented }\end{array}$ \\
\hline Environmental awareness & $\begin{array}{l}\text { Whether respondent is aware about } \\
\text { environmental impacts by waste or not }\end{array}$ & $\begin{array}{l}1=\mathrm{Yes} \\
0=\mathrm{No}\end{array}$ \\
\hline Waste collection service & Have access to waste collection service or not & $\begin{array}{l}1=\text { Yes } \\
0=\text { No }\end{array}$ \\
\hline Willingness to pay & $\begin{array}{l}\text { Whether respondent is willing to pay for } \\
\text { improved waste collection service or not }\end{array}$ & $\begin{array}{l}1=\text { Yes } \\
0=\text { No }\end{array}$ \\
\hline Make compost & $\begin{array}{l}\text { Whether the household use their degradable } \\
\text { waste to make compost or not }\end{array}$ & $\begin{array}{l}1=\text { Yes } \\
0=\text { No }\end{array}$ \\
\hline Segregated waste for a week & $\begin{array}{l}\text { Whether the household segregated the waste } \\
\text { for a week or not }\end{array}$ & $\begin{array}{l}1=\text { Yes } \\
0=\text { No }\end{array}$ \\
\hline
\end{tabular}

Note. *The exchange rate as of August 31, 2017 (Nepal Rastra Bank, 2017)

\section{Results and Discussion}

\subsection{Waste Generation and Waste Composition in the Study Area}

This study found that the per capita household waste generation in Gorkha municipality is $0.24 \mathrm{~kg} / \mathrm{day}$ and an estimated total household waste generation is 9.4 tonnes/day. Organic waste constitutes the major share of household waste, which is about $47.25 \%$, followed by recyclable materials, which is about $37.52 \%$ and remaining waste constitute about $15.23 \%$. The detail composition of each waste types is presented in Table 2 . Organic waste if disposed indiscriminately, creates environmental and health hazards but can be managed efficiently by making compost. If household waste is segregated at source then there is a huge potential to recover quality recyclable materials. If organic waste and recyclable materials from household waste can be managed properly, only a small fraction of household waste needs to be disposed and it reduces a huge burden for the local government. 
Table 2. Summary of continuous variables

\begin{tabular}{ll}
\hline Category & Description \\
\hline Organic waste & $\begin{array}{l}\text { Kitchen waste (vegetable and fruit peelings, eggshells, food leftovers, } \\
\text { tainted food, tea leaves, bones, oil, etc.) and yard waste (leaves, } \\
\text { grasses, weeds, plants, flowers, woods, branches, etc.) }\end{array}$ \\
Recyclable materials: & Aluminum cans, broken construction steel rods, broken umbrella \\
Metal & metal rods and old utensils. \\
& Notebooks, books, newspapers and cardboards. \\
Paper and paper products & Polyethylene Terephthalate bottles such as beverage bottles; \\
Plastic & low-density polyethylene such as trash bags and high-density \\
& polyethylene plastics such as bags and sacks, sheets, toiletries \\
& containers, condiment containers, water bottles, drums, toys; and \\
& polystyrene such as food packages. \\
Beer bottles, alcohol bottles, jars and medicine bottles. \\
Old clothes. \\
Glass & Slippers, shoes and belts. \\
Rubber and leather & Ceramics, medicines, light bulbs (Compact fluorescent, incandescent \\
bulbs), batteries, electronics (radios, wires) and inert waste.
\end{tabular}

Source: Field survey (2015)

\subsection{Characteristics of Households in the Study Area}

This study found that household heads are predominantly male (73.82\%), and the average size of the household is 3.72 that is similar to the national census result of 3.69 (Central Bureau of Statistics [CBS], 2014a). The average monthly household income is found to be NRs. 36,854.20 (360.86 US\$) but there is a huge difference between the minimum [NRs. 8020 (78.53 US\$)] and maximum [NRs. 244,083 (2389.92 US\$)] household income. One of the reasons for this huge difference is because poor households in very rural setting within the municipality were also considered in this study. Majority of the households who participated in this study lives in their own house (87.28\%). Only about $36.66 \%$ of the households have the waste collection service provided by the municipality. More than half of the surveyed households $(58.35 \%)$ are aware about the environmental impacts caused by waste, but the remaining households (41.65\%) who are not aware about such adverse effects also constitute a significant percentage.

About $61 \%$ of the respondents are willing to pay for the improved waste collection service. This finding is somewhat similar to other similar studies where more than $60 \%$ of the respondents provided positive response that they are willing to pay for improved waste management services (Anjum, 2013; Eshun \& Nyarko, 2011; Jones, Evangelinos, Halvadakis, Iosifides, \& Sophoulis, 2010; Karthigarani \& Elangovan, 2016; Mahima \& Thomas, 2013; Roy \& Deb, 2013). The total number of households who use their waste to make compost is slightly greater than those households who do not make compost. About $52 \%$ of the surveyed households make compost and about $48 \%$ do not make compost. Most of the households segregated waste for a week (95.76\%) and they were very happy with the practice, because they saw changes in the cleanliness of the house and surrounding as well as behavior among the household member to manage waste properly. Although, almost all of the households segregated waste for a week, only $67.33 \%$ of them are willing to segregate waste in future if the government enforces the law. Some of the main reasons for those households who do not want to segregate waste in future are:

(i) Do not want to be forced to segregate waste.

(ii) Law implementation will not be successful because people will not obey the law.

(iii) Generate less amount of waste so it can be self-managed.

The summary of these characteristics of the households in this study are also summarized in Table 3 and Table 4 . 
Table 3. Summary of continuous variables

\begin{tabular}{llllll}
\hline Variable & Observation & Mean & Standard Deviation & Minimum & Maximum \\
\hline Income & 401 & 36854.20 & 28509.48 & 8020 & 244083 \\
Household Size & 401 & 3.72 & 1.36 & 1 & 9 \\
\hline
\end{tabular}

Source: Field survey (2015)

Table 4. Summary of categorical variables

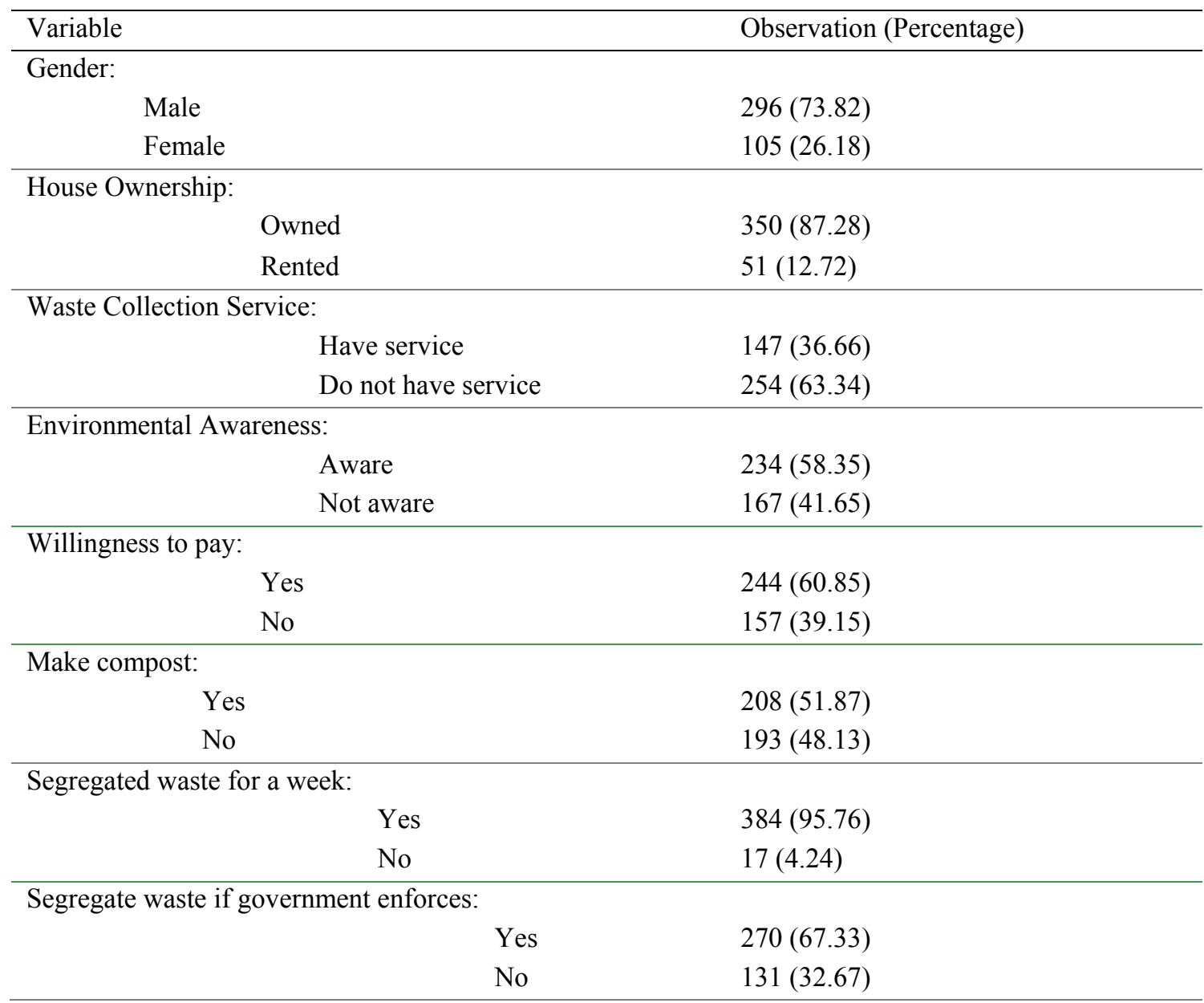

Source: Field survey (2015)

\subsection{Factors Influencing Households' Willingness to Segregate Waste if the Government Enforces Law}

The results from the logit regression model is presented in Table 5. All 401 observations are used in this analysis. The log likelihood for this fitted model is -185.59087 and the likelihood ratio (LR) chi-square of 135.53 (df=9) with a p-value 0.0000 (significant at $1 \%$ ) states that this model is statistically significant and as a whole fit significantly better than an empty model, i.e., only with the dependent variable. 
Table 5. Logit regression results of factors influencing willingness to segregate waste if the government enforces

\begin{tabular}{lllll}
\hline Independent Variables & Coefficient & Standard Error & Z-statistics & Marginal Effect \\
\hline Income & $-0.000011^{* *}$ & 0.000005 & -2.30 & -0.000002 \\
Household size & -0.039201 & 0.096006 & -0.41 & -0.005904 \\
Gender & $-0.517621^{*}$ & 0.311353 & -1.66 & -0.077964 \\
House ownership & -0.196384 & 0.389795 & -0.50 & -0.029579 \\
Environmental awareness & $1.740836^{* * *}$ & 0.264437 & 6.58 & 0.262203 \\
Waste collection service & $1.117412^{* * *}$ & 0.303545 & 3.68 & 0.168304 \\
Willingness to pay & $0.725199^{* * *}$ & 0.272514 & 2.66 & 0.109229 \\
Make compost & $1.256562^{* * *}$ & 0.274483 & 4.58 & 0.189262 \\
Segregated waste for a week & $1.874554^{* * *}$ & 0.583208 & 3.21 & 0.282344 \\
Constant & $-2.167573^{* * *}$ & 0.783154 & -2.77 & \\
\hline Number of observations & \multicolumn{5}{c}{401} \\
Log likelihood & \multicolumn{5}{c}{185.59087} \\
LR chi ${ }^{2}(9)$ & \multicolumn{5}{c}{$0.0000^{* * *}$} \\
Probability > chi ${ }^{2}$ & \multicolumn{5}{c}{0.2675} \\
Pseudo $\mathrm{R}^{2}$ & \multicolumn{5}{c}{} \\
\hline
\end{tabular}

Source: Field survey (2015)

Note. $*$ significant at $10 \%, * *$ significant at $5 \%$ and $* * *$ significant at $1 \%$

This study found that the significant variables that influence households' willingness to segregate waste in future if the government enforces the law are income, gender, environmental awareness, waste collection service, willingness to pay, make compost and segregated waste for a week. Only Household size and house ownership variables do not have any statistically significant influence on the households' willingness to segregate waste.

The total average income of the household is statistically significant at 5\% level and it negatively influences households' willingness to segregate decision. The marginal effect result shows that a unit increase in household income would decrease the likelihood for households' willingness to segregate waste by $0.000002 \%$, i.e., if the monthly household income increases by NRs. 100,000 (970.91 US\$), the likelihood for households' willingness to segregate decreases by $0.2 \%$. Even though, the effect is very less, it is important to understand the negative effect of the income variable.

The gender variable is statistically significant at $10 \%$ level, with a negative coefficient value. This shows that female household heads are more likely to segregate waste in future than male household heads. This could be because in Nepal females are responsible to do household chores, which also includes management of household waste. Hence, they are more effected and concerned for proper management of waste.

The environmental awareness variable has a positive coefficient and is statistically significant at $1 \%$ level. This result shows that households are more likely to segregate waste if they are aware about the adverse impacts of waste on environment by $26.22 \%$ than those households who are not aware.

The waste collection service variable is significant at $1 \%$ level of significance with positive coefficient. This shows that the households who have the current waste collection service must be aware about the negative consequences if they do not follow the law and that their waste may not be collected if they do not segregate waste.

The willingness to pay variable is statistically significant at $1 \%$ level of significance with positive coefficient. This implies that, households who are willing to pay for the improved services are more concerned about the proper management of waste and they want to be a responsible citizen by obeying the law. The households who are willing to pay for the improved service is likely to segregate waste than those who are not willing to pay by $10.92 \%$.

Households who make compost are more likely to segregate waste than who do not make compost by $18.93 \%$, which is statistically significant at $1 \%$ level of significance. This could be because these households are using their degradable waste to make compost and for that they might have already been segregating their waste. 
Households who segregated waste for a week are also likely to segregate waste in future by $28.23 \%$ than those households who did not segregate waste for a week. This variable is statistically significant at $1 \%$ level of significance. This could be because, these households saw the changes in cleanliness of their house and also could recover recyclable waste. They understood the benefit of waste segregate and so would like to continue segregating waste if the government enforces the law.

Although the national government has enacted law for waste segregation at source, local government in the study area has not implemented the law. The significant variables found from this study can be taken as a guiding tool to understand the characteristics of the households before enforcing the law. Although household income negatively influences the waste segregation behavior, environmental awareness and waste segregation practice can positively influence the waste segregation behavior of the household. Therefore, concerned stakeholders should educate and make households aware about the importance of waste segregation and environmental impacts caused by waste. This would encourage the households with higher income and also the male household heads to segregate waste. Households who make compost is highly statistically significant with willingness to segregate waste. The concerned stakeholders should provide training programs so that quality compost can be made and also to encourage other households to make compost. Furthermore, the concerned stakeholders should also make a market to buy and sell the compost. Households who are willing to pay for the improved waste collection service are also likely to segregate waste if the government enforces the law. Therefore, the government should improve the current solid waste management services provided in the municipality to encourage household waste segregation. Currently, waste collection service is provided only in few areas within the municipality and households who have such service are willing to segregate waste. For the local government, it may not be feasible to provide waste collection service to all the areas within the municipality. But, as a pilot phase, the local government can enforce waste segregation to the areas where it provides the waste collection service. In long term, after the municipality has enough technical, financial and manpower resources to provide waste collection service to all the areas, waste segregation at source can be enforced for the whole municipality.

\section{Conclusion}

This study tried to highlight the importance of waste segregation at source for effective management and identify the determinants for willingness of households to segregate waste in future if the government enforces the law. This study found that environmental awareness, waste collection service, willingness to pay, make compost, and segregated waste for a week variables are statistically significant at $1 \%$ level of significance. Income variable is significant at $5 \%$ level of significance and gender variable is significant at $10 \%$ level of significance. Almost all of the households $(95.76 \%)$ segregated waste for a week for this study but only $67.33 \%$ of them wants to segregate waste in future. The government should educate the households about the importance of waste segregation and also provide relevant training to encourage households to segregate waste. Policy implementation is a huge challenge for the government and so the findings from this study could be taken into consideration to enforce the law of waste segregation at source in the study area as well as other municipalities in Nepal and even in other developing countries.

\section{Acknowledgments}

I am very grateful to staffs of Gorkha municipality for their insightful information and support for this study. I would like to thank all the enumerators who assisted in conducting fieldwork in all the wards of the municipality. Sincere appreciation also goes to all the respondents for their valuable time.

\section{References}

Addai, K. N., \& Danso-Abbeam, G. (2014). Determinants of willingness to pay for improved solid waste management in Dunkwa-on-Offin, Ghana. Journal of Agriculture and Environmental Sciences, 3(1), 1-9.

Aggrey, N., \& Douglason, O. G. (2010). Determinants of willingness to pay for solid waste management in Kampala City. Current Research Journal of Economic Theory, 2(3), 119-122.

Anjum, R. (2013). Willingness to pay for solid waste management services: A case study of Islamabad (No. 3). Islamabad, Pakistan.

Asian Development Bank [ADB]. (2013). Solid waste management in Nepal: Current status and policy recommendations. Mandaluyong City, Philippines: Asian Development Bank. Retrieved from https://www.adb.org/sites/default/files/publication/30366/solid-waste-management-nepal.pdf

Atthirawong, W. (2016). Factors affecting household participation in solid waste management segregation and recycling in Bangkok, Thailand. In 30th European Conference on Modelling and Simulation. https://doi.org/10.7148/2016-0198 
Awunyo-Vitor, D., Ishak, S., \& Jasaw, G. S. (2013). Urban households' willingness to pay for improved solid waste disposal services in Kumasi metropolis, Ghana. Urban Studies Research, 2013, 1-8. https://doi.org/10.1155/2013/659425

Ball, R., \& Lawson, S. M. (1990). Public attitudes towards glass recycling in Scotland. Waste Management \& Research, 8, 177-192.

Bernstad, A. (2014). Household food waste separation behavior and the importance of convenience. Waste Management, 34(7), 1317-1323. https://doi.org/10.1016/j.wasman.2014.03.013

Bhattarai, K. (2015). Households' willingness to pay for improved solid waste management in Banepa municipality, Nepal. Environment and Natural Resources Journal, 13(2), 14-25.

Central Bureau of Statistics. (2004). Nepal living standards survey, (December), 1-146. https://doi.org/november, 2011

Central Bureau of Statistics [CBS]. (2014a). National population and housing census 2011: Urban tables (Vol. 07, Part I). Kathmandu, Nepal: Central Bureau of Statistics.

Central Bureau of Statistics [CBS]. (2014b). Population monograph of Nepal (Vol. III). Kathmandu, Nepal: Central Bureau of Statistics. Retrieved from http://cbs.gov.np/image/data/Population/Population Monograph of Nepal 2014/Population Monograph V03.pdf

Chu, Z., Wang, W., Wang, B., \& Zhuang, J. (2016). Research on factors influencing municipal household solid waste separate collection: Bayesian belief networks. Sustainability, $8(2), 152$. https://doi.org/10.3390/su8020152

De Feo, G., \& De Gisi, S. (2010a). Domestic separation and collection of municipal solid waste: Opinion and awareness of citizens and workers. Sustainability, 2(5), 1297-1326. https://doi.org/10.3390/su2051297

De Feo, G., \& De Gisi, S. (2010b). Public opinion and awareness towards MSW and separate collection programmes: A sociological procedure for selecting areas and citizens with a low level of knowledge. Waste Management, 30(6), 958-976. https://doi.org/10.1016/j.wasman.2010.02.019

Derksen, L., \& Gartrell, J. (1993). The social context of recycling. American Sociological Review, 58(3), 434-442. Retrieved from http://www.jstor.org/stable/2095910

Desa, A., Kadir, N. B. A., \& Yusooff, F. (2011). A study on the knowledge, attitudes, awareness status and behaviour concerning solid waste management. Procedia Social and Behavioral Sciences, 18, 643-648. https://doi.org/10.1016/j.sbspro.2011.05.095

Eshun, T. B., \& Nyarko, F. (2011). Willingness to pay for improved waste management services: The case of Tarkwa-Nsuaem municipality. Asian-African Journal of Economic and Econometrics, 11(1), 187-196.

Everett, J., \& Peirce, J. W. (1993). Curbside recycling in the U.S.A.: Convenience and mandatory participation. Waste Management \& Research. https://doi.org/10.1006/wmre.1993.1006

Hoornweg, D., \& Bhada-Tata, P. (2012). What a waste: A global review of solid waste management (Urban Development Series - Knowledge Papers No. 15). Washington, DC, USA: World Bank.

Housing Recovery and Reconstruction Platform - Nepal [HRRP]. (2016). NEPAL: Gorkha District - Gorkha Municipality. Retrieved October 2, 2016, from http://hrrpnepal.org/maps/

Ittiravivongs, A. (2012). Factors influence household solid waste recycling behaviour in Thailand: An integrated perspective. WIT Transactions on Ecology and the Environment, 167, 437-448. https://doi.org/10.2495/ST110391

Jones, N., Evangelinos, K., Halvadakis, C. P., Iosifides, T., \& Sophoulis, C. M. (2010). Social factors influencing perceptions and willingness to pay for a market-based policy aiming on solid waste management. Resources, Conservation \& Recycling, 54, 533-540. https://doi.org/10.1016/j.resconrec.2009.10.010

Karthigarani, R., \& Elangovan, V. (2016). Household willingness to pay for better solid waste management in Sivagangai district, Tamil Nadu. In XVII Annual International Seminar Proceedings (pp. 171-182). Retrieved from http://www.internationalseminar.org/XVII_AIS/TS1_PDF/10.R. Karthigarani \& V. Elangovan.pdf

Kato, T., Tran, A. ., \& Hoang, H. (2015). Factors affecting voluntary participation in food residue recycling: A case study in Da Nang, Vietnam Nam. Sustainable Environment Research, 25(2), 93-101.

Lober, D. J. (1996). Municipal solid waste policy and public participation in household source reduction. Waste Management \& Research, 14(2), 125-143. https://doi.org/10.1177/0734242X9601400203 
Mahima, S., \& Thomas, S. (2013). Estimating households willingness to pay for solid waste management with special reference to Palakkad district in Kerala. International Journal of Social Science \& Interdisciplinary Research, 2(1), 73-80.

Mani, S., \& Singh, S. (2016). Sustainable Municipal Solid Waste Management in India: A Policy Agenda. Procedia Environmental Sciences, 35, 150-157. https://doi.org/10.1016/j.proenv.2016.07.064

Martin, M., Williams, I. D., \& Clark, M. (2006). Social, cultural and structural influences on household waste recycling: A case study. Resources, Conservation and Recycling, 48(4), 357-395. https://doi.org/10.1016/j.resconrec.2005.09.005

Mary, O., \& Adelayo, A. (2014). Household willingness to pay for improved solid waste management in Akinyele local government area. Journal of Biology, Agriculture and Healthcare, 4(18), 76-82.

Matter, A., Dietschi, M., \& Zurbrügg, C. (2013). Improving the informal recycling sector through segregation of waste in the household - The case of Dhaka Bangladesh. Habitat International, 38, 150-156. https://doi.org/10.1016/j.habitatint.2012.06.001

McDonald, S., \& Oates, C. (2003). Reasons for non-participation in a kerbside recycling scheme. Resources, Conservation and Recycling, 39(4), 369-385. https://doi.org/10.1016/S0921-3449(03)00020-X

Miafodzyeva, S., \& Brandt, N. (2013). Recycling behaviour among householders: Synthesizing determinants via meta-analysis. Waste and Biomass Valorization, 4(2), 221-235. https://doi.org/https://doi.org/10.1007/s12649-012-9144-4

Minton, A. P., \& Rose, R. L. (1997). The effects of environmental concern on environmentally friendly consumer behaviour: An exploratory study. Journal of Business Research, 40(96), 37-48. https://doi.org/10.1016/S0148-2963(96)00209-3

Nepal Rastra Bank. (2017). Foreign exchange rates. Retrieved September 1, 2017, from https://www.nrb.org.np/fxmexchangerate.php?YY=2017\&MM=08\&DD=31\&B1=Go

Noehammer, H. C., \& Byer, P. H. (1997). Effect of design variables on participation in residential curbside recycling programs. Waste Management \& Research, 15(4), 407-427. https://doi.org/https://doi.org/10.1006/wmre.1996.0096

Oteng-Ababio, M. (2010). Solid waste management in Ghana: Willingness-to-pay for improved services. Ghana Journal of Geography, 2, 85-107.

Otitoju, T. A. (2014). Individual attitude toward recycling of municipal solid waste in Lagos, Nigeria. American Journal of Engineering Research, 3(7), 78-88.

Perrin, D., \& Barton, J. (2001). Issues associated with transforming household attitudes and opinions into materials recovery: A review of two kerbside recycling schemes. Resources, Conservation and Recycling, 33(1), 61-74. https://doi.org/10.1016/S0921-3449(01)00075-1

Roy, A. T., \& Deb, U. (2013). Households willingness to pay for improved waste management in Silchar municipal area: A case study in Cachar District, Assam. IOSR Journal of Humanities and Social Science, 6(5), 21-31.

Song, Q., Wang, Z., \& Li, J. (2016). Residents' attitudes and willingness to pay for solid waste management in Macau. Procedia Environmental Sciences, 31, 635-643. https://doi.org/10.1016/j.proenv.2016.02.116

Steuteville, R. (1995). The state of garbage in America. BioCycle, 4, 54-63.

The World Bank. (2016). Urban solid waste management. Retrieved July 21, 2016, from http://web.worldbank.org/WBSITE/EXTERNAL/TOPICS/EXTURBANDEVELOPMENT/EXTUSWM/0, menuPK:463847 pagePK:149018 piPK:149093 theSitePK:463841,00.html

Tonglet, M., Phillips, P. S., \& Bates, M. P. (2004). Determining the drivers for householder pro-environmental behaviour: Waste minimisation compared to recycling. Resources, Conservation and Recycling, 42(1), 27-48. https://doi.org/10.1016/j.resconrec.2004.02.001

Xu, L., Ling, M., Lu, Y., \& Shen, M. (2017). External influences on forming residents' waste separation behaviour: Evidence from households in Hangzhou, China. Habitat International, 63, 21-33. https://doi.org/10.1016/j.habitatint.2017.03.009

Yamane, T. (1967). Statistics: An introductory analysis (2nd ed.). New York: Harper and Row.

Yau, Y. (2010). Domestic waste recycling, collective action and economic incentive: The case in Hong Kong. Waste Management, 30(12), 2440-2447. https://doi.org/10.1016/j.wasman.2010.06.009 
Zhang, H., \& Wen, Z.-G. (2014). Residents' household solid waste (HSW) source separation activity: A case study of Suzhou, China. Sustainability, 6(9), 6446-6466. https://doi.org/10.3390/su6096446

Zurbrugg, C. (2002). Solid waste management in developing countries.

\section{Copyrights}

Copyright for this article is retained by the author(s), with first publication rights granted to the journal.

This is an open-access article distributed under the terms and conditions of the Creative Commons Attribution license (http://creativecommons.org/licenses/by/4.0/). 